\title{
Evaluation of ecosystem services: A case study in the middle reach of the Heihe River Basin, Northwest China
}

\author{
Hongji Li ${ }^{a}$, Zhihui $\mathrm{Li}^{\mathrm{b}, \mathrm{c}, \mathrm{d}, *}$, Zhaohua $\mathrm{Li}^{\mathrm{a}}$, Jing Yu ${ }^{\mathrm{a}}$, Bing Liu ${ }^{\mathrm{e}}$ \\ ${ }^{a}$ Faculty of Resources and Environmental Science, Hubei University, China \\ ${ }^{\mathrm{b}}$ Institute of Geographic Sciences and Natural Resources Research, Chinese Academy of Sciences, China \\ ${ }^{\mathrm{C}}$ Center for Chinese Agricultural Policy, Chinese Academy of Sciences, Beijing 100101, China \\ ${ }^{\mathrm{d}}$ University of Chinese Academy of Sciences, Beijing 100049, China \\ ${ }^{\mathrm{e}}$ College of Geomatics, Shandong University of Science and Technology, China
}

\section{A R T I C L E I N F O}

\section{Article history:}

Received 2 February 2015

Received in revised form 29 June 2015

Accepted 22 July 2015

Available online 4 August 2015

\section{Keywords:}

Ecosystem services values

Ecosystem services value coefficients

Land use change

Heihe River Basin

\begin{abstract}
A B S T R A C T
Ecosystem services evaluation aims at understanding the status of ecosystem services on different spatial and temporal scale. In this paper, we selected the middle reach of the Heihe River Basin (HRB), which is the second largest inland river basin in China, as one of the typical area to estimate the ecosystem services values (ESVs) corresponding to the land use changes. Based on the land use data and ecosystem service value coefficients, the total ecosystem services values (TESVs) of the middle reach of the HBR are quantitatively calculated, which were $9.244 \times 108,9.099 \times 108,9.131 \times 108$ and $9.146 \times 108$ USD in $1988,2000,2005$ and 2008 respectively. During 1988-2008, the decrease of grassland, forest land, water area and unused land contributed $148.94 \%, 57.85 \%, 87.87 \%$ and $16.42 \%$ respectively to the net loss of TESVs, while the dramatic increase of cultivated land improved the TESVs with contribution of $-211.08 \%$ to the net loss of TESVs. Expansion of cultivated land, which especially caused the loss of grassland and forest land, directly exerted negative impacts on the provision of ecosystem services in the study area. The findings of this research indicated that land use change was an important form of human activities, which had a strong impact on ecosystem services.
\end{abstract}

(c) 2015 Elsevier Ltd. All rights reserved.

\section{Introduction}

Ecosystem services are critical to humans being's life, which directly and indirectly provide essential materials and benefits to the sustainable development of human society and environment (Costanza et al., 1997). There have many researches been conducted in the classification and evaluation of ecosystem services, and the analyses of the relationship between ecosystem services and land use changes (Deng et al. 2013; Li et al., 2013). Since the concept of ecological system being put forward by Tansley (1935), relevant studies of ecological systems have gradually formed a scientific system, and further been strengthened since the end of 20th century. Among those studies, Daily (1997) carried out research of ecosystem services classification and evaluation. Costanza et al. (1997) mainly focused on the global ecosystem services classification and evaluation and summarized 17 types of the ecosystem services according to the estimation of 16 kinds of

\footnotetext{
* Corresponding author at: Institute of Geographic Sciences and Natural Resources Research, Chinese Academy of Sciences, China.

E-mail addresses: lizh.12b@igsnrr.ac.cn, zhihuilee@126.com (Z. Li).
}

biome in monetary form. Bockstael et al. (2000) conducted researches on measurement method of the economic valuation of ecosystem services and the analysis and generalization of the system. Groot et al. (2002) presented a conceptual framework and typology for describing, classifying and assessing ecosystem functions, goods and services in a clear and consistent manner. Farber et al. (2002) illustrated the concept of ecosystem service value and evaluation methods, which provided a theoretical basis for government decision-making. Howarth and Farber (2002) examined the role of the value of ecosystem services (VES) concept in measuring trends in human well-being. Chee (2004) conducted a critical review on the framework, tools and approaches that can be applied to estimate the economic value of ecosystem services, comprehensive management decision-making in social and economic benefits, etc., from an ecological perspective.

As the concept of ecosystem services being acknowledged, many methodological frameworks have been put forward to analyze and evaluate the ecosystem services, which make ecosystem services have become a popular scientific topic, especially in the last two decades. However, considering spatial and temporal scales, the links between ecosystem services and human activities 
are more complicated (Pereira et al., 2005). According to the report of Millennium Ecosystem Assessment (MEA), it showed that human activities had induced more rapid and extensive changes in ecosystems over the past 50 years compared to other period, which mainly due to the rapidly growing demands of humans for food, fresh water, timer, fiber and fuel etc. This has resulted in a substantial and largely irreversible loss in the diversity of life on the earth. The future capability of ecosystems to provide these services is determined by changes in socioeconomic characteristics, land use, biodiversity, atmospheric composition and climate (Metzger et al., 2006). Among these factors, land use conversions were identified as the most significant factors driving the changes in ecosystem services, affecting human well-being and threatening the survival of other species (Geneletti, 2013). It was also identified that the changes in the extent and composition of different land use type had large impacts on the provision of ecosystem services, biodiversity conservation and returns to landowners (Polasky et al., 2011). Land use changes typically impact on the capacity of ecosystems to provide goods and services to the human society, thus resulted in large changes in ecosystem service supply (Schroter et al., 2005).

It has been identified that ecosystem services were declining over the previous decades, while there is no common method to evaluate the impacts of land use change on ecosystem services. However, the method that links spatial land cover information derived from remote sensing (RS), land survey and Geographic Information System (GIS), with data from monitoring, statistics, modeling or interviews, was mostly applied to asses and transfer ecosystem service supply to different spatial and temporal scales (Burkhard et al., 2012). Thus, regarding the depicting of ecosystem services, many researchers used different methods to spatially analyze and map the changes of ecosystem services. For example, Haines-Young et al. (2012) developed an approach, which is mainly expert- and literature-driven method, to map indicators of the potential of ecosystems to supply ecosystem services, and to analyze the impact of land cover changes on ecosystem services. Troy and Wilson (2006) designed a decision framework to estimate ecosystem service flow values based on the query of relevant economic valuation studies and to spatially explicitly map the results based on GIS. Egoh et al. (2008) evaluated and mapped the production of five ecosystem services, and further tested the correlation between primary production and these five services to check whether the primary production can act as a whole representative measurement of ecosystem services. Naidoo (2008) reviewed the theory and available data to quantify imperfect global proxies for only four ecosystem services. Ayanu et al. (2012) used different remote sensing systems, sensor types, and methods that can be applied to quantify provisioning and regulatory services. Jackson et al. (2013) introduced a GIS framework (Polyscape), which was designed to explore spatially explicit synergies and trade-offs among ecosystem services to support landscape management. Leh et al. (2013) presented a methodology to quantify and assess the changes in multiple ecosystems services induced by land use changes using the Integrated Valuation of Ecosystem Services and Tradeoffs (InVEST) model. The studies mentioned above can be divided to two types, one mostly focused on the evaluation and mapping of the economic values of ecosystem services, while the other tried to apply models to quantify the provision of physical ecosystem services.

Further, recent studies of ecosystem services mainly focus on the large scale comprehensive systematic analyses of ecosystem service function and value assessment, while quantitative research on ecosystem services on small scale is relatively less. In this paper, taking the middle reach of the Heihe River Basin as study area, combining land use datasets with the information on ecosystem service value coefficients derived from literature review, we aimed to evaluate the ecosystem services values (ESVs) and further to analyze the impacts of land use changes on ecosystem services. As Heihe River Basin is an ecological fragile area, where water resource plays a key role in sustaining ecosystem services, and in return, the improvement of ecosystem services will help alleviate the water scarcity pressures (Deng and Zhao, 2015; Wu et al., 2015; Li et al., 2015), thus the comprehensive analyses can support the exploration of sustainable land use management for mitigating the impacts on water scarcity and ecosystem services.

\section{Data and method}

\subsection{Study area}

The Heihe River Basin (HRB) is the second largest inland river basin located in the arid zone of Northwest China, with annual rainfall of $100-200 \mathrm{~mm}$. The total length of the main stream river is more than $800 \mathrm{~km}$, and the river basin covers an area of $130,000 \mathrm{~km}^{2}$ (Xiao et al., 2014). The HRB can be divided into three parts, the upper reach region, which is the main source area of water resources, the supply of water mainly comes from the Qilian Mountains in the upper reach; the middle reach region, which is the irrigation agriculture economic zone and main water consumption area; and the lower reach region, which is mainly dominated by desert animal husbandry (Xiao et al., 2015). We select the middle reach of the HRB as study area, it covers Ganzhou district, Minle, Shandan, Linze and Gaotai county (Fig. 1). The land development in the middle reach is the most intensive in the HRB, and industrial and agricultural production are mainly concentrated in the oasis area within the middle reach. While, due to agricultural irrigation water diversion and intensive water consumption of industrial production, water problems have become an important restriction factor of the ecological and socioeconomic sustainable development, leading to serious ecological environmental problems, such as degradation of natural oasis, soil erosion, and desertification.

\subsection{Data}

Two types of data sets were collected. On the one hand, the land-use data in 1998, 2000, 2005 and 2008 used in this study were derived from the Resources and Environment Scientific Data Center, Chinese Academy of Sciences, which were processed based on the remotely sensed digital imagines (Deng et al., 2010; Liu et al., 2010; Wu et al., 2013; Deng et al., 2014). The land use was classified into six types, including cultivated land, forest land, grassland, water area, built-up land and unused land (Fig. 2).

On the other hand, different ecosystems have different functions and therefore different capacities to provide ecosystem services. According to the theory of ecosystem service values (ESVs) put forwarded by Costanza et al. (1997), an ecosystem is composed of sub-ecosystems including cropland ecosystem, forest ecosystem, grassland ecosystem, water body ecosystem, wetland ecosystem and urban ecosystem. Based on the ecological characteristics of land use in the middle reach of the HRB, each type of land was matched with one type of sub-ecosystem. Ecosystem services supply capacities were assessed for the five major different land-use types in the study area. We choose the expert- and literaturedriven method to get the information about the capabilities of different land use types to provide ecosystem services and the values of different ecosystem services, during which we collected relevant empirical studies which have the similar research context (Ausseil et al., 2013; Burkhard, 2009; Müller, 2007), and further we analyzed and extracted ecosystem service value coefficients associated with each land-use type. Table 1 shows the ecosystem service 


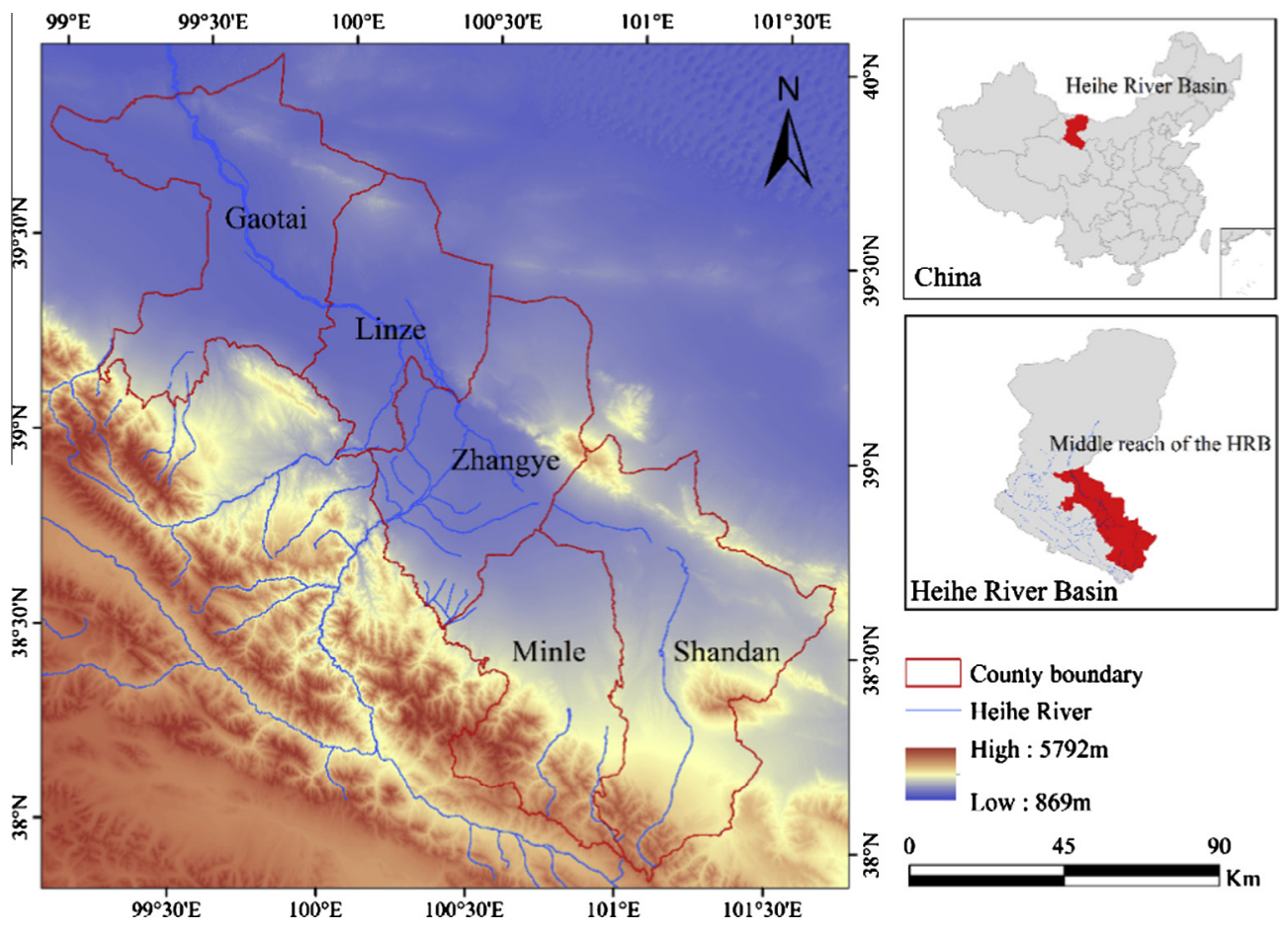

Fig. 1. Location of the middle reach of the HRB.



Fig. 2. Land-use in the middle reach of the HRB in 2008. 
Table 1

Estimated values of ecosystem services per unit area (USD km ${ }^{-2}$ year $^{-1}$ ).

\begin{tabular}{|c|c|c|c|c|c|c|}
\hline \multirow[t]{2}{*}{ Ecosystem service } & \multirow[t]{2}{*}{ Secondary service function } & Farmland ecosystem & Forest ecosystem & Grassland ecosystem & Water body ecosystem & Desert ecosystem \\
\hline & & Cultivated land & Forest land & Grassland & Water areas & Unused land \\
\hline \multirow[t]{2}{*}{ Support services } & Food production & 5988.00 & 1976.00 & 2574.80 & 3173.60 & 119.73 \\
\hline & Production of raw materials & 2335.33 & 17844.27 & 2155.73 & 2095.87 & 239.47 \\
\hline \multirow[t]{4}{*}{ Regulating services } & Gas conditioning & 4311.33 & 25868.13 & 8982.00 & 3053.87 & 359.33 \\
\hline & Climate regulation & 5808.40 & 24371.20 & 9341.33 & 12335.33 & 778.40 \\
\hline & Hydrological adjusting & 4610.80 & 24490.93 & 9101.73 & 112394.80 & 419.20 \\
\hline & Waste disposal & 8323.33 & 10299.33 & 7904.13 & 88921.87 & 1556.93 \\
\hline \multirow[t]{2}{*}{ Supply service } & Retention soil & 8802.40 & 24071.73 & 13413.07 & 2455.07 & 1018.00 \\
\hline & Biodiversity & 6107.73 & 27005.87 & 11197.60 & 20538.80 & 2395.20 \\
\hline \multirow[t]{2}{*}{ Cultural services } & Provide aesthetic landscape & 1018.00 & 12455.07 & 5209.60 & 26586.67 & 1437.07 \\
\hline & Total ESV coefficients $\left(V C_{i}\right)$ & 47305.32 & 168382.53 & 69879.99 & 271555.88 & 8323.33 \\
\hline
\end{tabular}

Note: Ecosystem service value coefficients (USD km ${ }^{-2}$ year $^{-1}$ ) were adopted from Xie et al. (2008).

value coefficients of cultivated land, forest land, grassland, water area, and unused land (Xie et al., 2008). As the urban ecosystem services value calculation involves many factors, and built-up land accounts for only about $1.7 \%$ of the total land in this area, this study temporarily did not consider the value of ecosystem services of built-up land.

\subsection{Method for analyzing ecosystem services}

Based on the datasets, we conducted our analyses mainly aiming to evaluate the ecosystem services values and analyze the impacts of land use changes on ecosystem services. Classification of ecosystem services is the base to analyze the impacts of land use changes. Among different ecosystem services classification systems, two kinds were mostly applied in researches. The one is taking the regional ecosystem as a whole to classify the ecosystem services, and is mainly applied in the large scale studies (Radford and James, 2013). The other one is auxiliary ecosystem services classification system, which is designed for one particular ecosystem, such as forest ecosystem, water ecosystem, grassland ecosystem, etc. and it is mainly applied in small and medium-sized study area (Xie et al., 2003). On the basis of literature review of the current existing ecosystem service classification system, we summarized the integrated ecosystem services classification system, including four major categories and 20 types of ecosystem services, and further selected 9 major types to calculate the total ecosystem services values in the middle reach of the HRB. Ecosystem services evaluation mainly includes monetary evaluation and nonmonetary evaluation. Monetary evaluation method aims to estimate the total monetary value of biomass provided by ecosystems, mainly include alternative marketing method and marketing simulation method. Alternative marketing method is taking ecosystem services as a kind of product, further to estimate the market value of itself or of its alternative products. Marketing simulation method is to evaluate the ecosystem services through the virtual market, by adopting a series of methods such as questionnaire to explore people's willingness to pay for certain types of ecosystem services to indirectly evaluate its economic value. We adopted the classic method of quantitative valuation of ecosystem services that put forwarded by Xie et al. (2008). They made a set of questionnaires for 200 ecologists in 2002 in China based on the study results from Costanza et al. (1997) and then corrected their coefficients to get the average value coefficients of terrestrial sub-ecosystems in China. Further, they concluded a new ecosystem service evaluation system on the basis of questionnaire survey in 2002 and 2006, which were took on 700 Chinese professionals with ecology background (Xie et al., 2008). Based on the ecosystem service value coefficients calculated by Xie et al. (2008), we conducted the valuation of the ecosystem services in the middle reach of the HRB.
Applying the ecosystem service value coefficients to evaluate the ecosystem services of each land use types in the middle reach of the HRB, we calculated the total ecosystem services values (TESVs), which is actually the sum of the major 9 ecosystem services values of all sub-ecosystems obtained through multiplying the area of each sub-ecosystem by the total ESV coefficients $\left(V C_{i}\right)$ of corresponding sub-ecosystem type $i$, shown as follows:

$\operatorname{TESV}_{s}=\sum_{i=1}^{n} A_{i} \times V C_{i}$

where TESVs is the total ecosystem services values in a defined area, $A_{i}$ is the area of sub-ecosystem type $i, V C_{i}$ refers to the ecosystem service value coefficients corresponding to each sub-ecosystem type $i$.

\section{Results}

Human activities weakened some ecosystem services, meanwhile, enhanced the others. Land use changes caused by human activities have a direct impact on ecosystem services. Based on the land use data in 1988, 2000, 2005 and 2008 (Table. 2), we analyzed the land use changes, and further explored the impacts of land use changes on ecosystem services.

During 1988-2008, the forest land, water area, grassland and unused land showed a decreasing trend, while the built-up land and cultivated land showed an increasing trend in Table 2. The water area decreased mainly because of the building of a series of reservoirs and other water facilities. The forest land decreased from $1291.45 \mathrm{~km}^{2}$ in 1988 to $1257.75 \mathrm{~km}^{2}$ in 2008 . Built-up land has expanded with a big growth rate of $9.85 \%$ and the cultivated land has expanded with the biggest growth rate of $12.40 \%$, mainly due to the development of social economy, urban and rural population growth, which leading to significant increase in urban and rural built-up land.

Specifically, the change trends of the land use types were not consistent during the four periods. Forest land overall declined gradually from 1988 to 2008. Grassland firstly showed a decreasing trend but with slightly increase during 2005-2008. The water

Table 2

Land-use changes in the middle reach of the HRB, 1988-2008 $\left(\mathrm{km}^{2}\right)$.

\begin{tabular}{lrrrr}
\hline Land use type & \multicolumn{1}{l}{1988} & \multicolumn{1}{l}{2000} & \multicolumn{1}{l}{2005} & \multicolumn{1}{l}{2008} \\
\hline Cultivated land & 3529.03 & 3747.35 & 3974.34 & 3966.70 \\
Forest land & 1291.45 & 1272.96 & 1258.09 & 1257.75 \\
Grassland & 4661.91 & 4491.93 & 4430.96 & 4452.86 \\
Water area & 528.83 & 492.70 & 494.97 & 497.09 \\
Built-up land & 307.70 & 323.04 & 336.15 & 338.02 \\
Unused land & 8485.20 & 8476.14 & 8309.60 & 8291.71 \\
\hline
\end{tabular}


Table 3

TESVs in the middle of HRB, 1988-2008.

\begin{tabular}{|c|c|c|c|c|c|}
\hline \multirow[t]{2}{*}{ Land use types } & \multirow{2}{*}{$\begin{array}{l}\text { Ecosystem services unit } \\
\text { price per square kilometer } \\
\left(\text { USD km } \text { kear }^{-1} \text { ) }\right.\end{array}$} & \multicolumn{4}{|c|}{ The annual ESVs ( $10^{8}$ USD/year) } \\
\hline & & 1988 & 2000 & 2005 & 2008 \\
\hline Cultivated land & 47305.2 & 1.669 & 1.773 & 1.880 & 1.876 \\
\hline Forest land & 168382.53 & 2.175 & 2.143 & 2.118 & 2.118 \\
\hline Grassland & 69,880 & 3.258 & 3.139 & 3.096 & 3.112 \\
\hline Water area & 271555.87 & 1.436 & 1.338 & 1.344 & 1.350 \\
\hline Unused land & 8323.33 & 0.706 & 0.705 & 0.692 & 0.690 \\
\hline TESVs (Monetary in2007) & & 9.244 & 9.099 & 9.131 & 9.146 \\
\hline
\end{tabular}

Note: The total ecosystem services value calculation based on the research of Xie et al. (2008). Per unit area ecosystem services value: in 2007 USD/(km ${ }^{*}{ }^{*}$ year).

Table 4

Changes of ESVs in the middle reach of the HRB, 1988-2008.

\begin{tabular}{|c|c|c|c|c|}
\hline Land use type & $\begin{array}{l}\text { Changes in area, } \\
1988-2008\left(\mathrm{~km}^{2}\right)\end{array}$ & $\begin{array}{l}\text { Changes of ESVs, } \\
1988-2008\left(\text { USD } 10^{8}\right)\end{array}$ & $\begin{array}{l}\text { Change rate of the ESVs, } \\
1988-2008(\%)\end{array}$ & $\begin{array}{l}\text { Contribution to the net } \\
\text { changes in TESVs (\%) }\end{array}$ \\
\hline Cultivated land & 437.67 & 0.207 & 12.40 & -211.08 \\
\hline Forest land & -33.7 & -0.057 & -2.61 & 57.85 \\
\hline Grassland & -209.05 & -0.146 & -4.48 & 148.94 \\
\hline Water area & -31.74 & -0.086 & -6.00 & 87.87 \\
\hline Unused land & -193.49 & -0.016 & -2.28 & 16.42 \\
\hline TESVs (Monetary in 2007) & & -0.098 & -1.06 & 100 \\
\hline
\end{tabular}

area, accounting a low proportion in total land area, showed a greatly decreasing trend from 1988 to 2000, and with slightly increasing during 2000-2008. The area of built-up land changed obviously, showed a significant increasing during 1988-2000, which is the period that built-up land expended with high speed, and then from 2005 to 2008, the growth rate of built-up land slowed down. Unused land include permanent glaciers, mountains snow belt and secondary land use types such as desert, accounting the largest proportion in the area, which decreased slightly during the period. Overall, in the middle reach of the HRB, the land use changes are mainly dominated by urban expansion, cultivated land increasing, shrinkage of forestland, grassland and water areas.

The ecosystem service value coefficients adopted from Xie et al. (2008) refers to the relative potential ability of ecosystem to contribute ecosystem services and is defined as the economic value of national average agricultural production per hectare. Thus taking the socio-economic level in 2007 as a calculating reference basis, we calculated the TESVs in the middle reach of the HRB based on the ecosystem service value coefficients (Table 3 ). From 1988 to 2008, the TESVs fluctuated, with $9.244 \times 10^{8}$, $9.099 \times 10^{8}, 9.131 \times 10^{8}$ and $9.146 \times 10^{8}$ USD in year 1988 , 2000, 2005 and 2008 respectively. According to the research results of Wang and Zhang (2004), the average ecosystem services value of the HRB is $3.62 \times 10^{4} \mathrm{USD} \mathrm{km}^{-2}$ year $^{-1}$ in 2000 , which is lower than $4.92 \times 10^{4} \mathrm{USD} \mathrm{km}^{-2}$ year $^{-1}$, which is the calculated average ecosystem services value in this study area in 2000. As the study area are mainly occupied by oasis and cultivated land, while the whole HRB, especially the lower reach region of the HRB are mainly occupied by deserts, which will pull down the average values of the ecosystem services, thus relatively speaking, the average ecosystem services values of the study area should be higher than that of the whole basin, which indicated that the two results are consistent, verifying the reliability of our research results.

Along with the land-use changes, the changes of ESVs of each land-use types during 1988-2008 in the middle reach of the HRB were calculated in Table 4 . The TESVs is about $9.244 \times 10^{8}$ and $9.146 \times 10^{8}$ USD in 1988 and 2008 respectively, resulting in a net change of $-0.098 \times 10^{8}$ USD. During 1988-2008, the areas of cultivated land has been increasing because of extensive agricultural activities, which positively contributed $-211.08 \%$ to the net loss of the TESVs. While, the ecosystem services of grassland and forest land showed a decreasing trend. The decrease in the ESVs of grassland are the major cause of the loss of the TESVs, contributing $148.94 \%$ positively to the net loss of the TESVs, along with the changes in the ESVs of forest land, water area and unused land, totally contributed $311.08 \%$ positively to the net loss of the TESVs, overwhelmed the negative contribution of the increased ESVs in cultivated land during 1988-2008. The result indicated that, along with the human's extensive activities and socioeconomic development, the cultivated land expansion finally resulted in the loss of the TESVs in the study area during 19882008.

\section{Discussion and conclusion}

Maintenance of the ecosystem services is critical to sustainable socio-economic development, and quantitative evaluation of ecosystem services can help to extend the understanding of natural resources and ecosystem function, and further to provide information for decision making and guide the sustainable development of the society. In this paper, we quantitatively estimated the values of ecosystem services in the middle reach of the HRB during 19882008 , with the adoption of ecosystem service value coefficients put forward by Xie et al. (2008). The findings showed the TESVs overall showed a decreasing trend along with the land use changes, decreased from $9.244 \times 10^{8}$ USD in 1988 to $9.146 \times 10^{8}$ USD in 2008. Among which, the decrease of grassland, forest land, water area and unused land contributed 148.94\%, 57.85\%, 87.87\% and $16.42 \%$ respectively to the net loss of TESVs, while the dramatic increase of cultivated land improved the TESVs with contribution of $-211.08 \%$ to the net loss of TESVs, together the land use changes totally exerted a negative impacts on the TESVs. Due to that it is very difficult to evaluate the ecosystem services values of the urban ecosystem, the ecosystem services of the built-up land, park land, green spaces etc. in the urban area were not taken into account. Thus the estimated TESVs in this paper should be lower than the actual values.

The results indicated that, land use changes, as an important form of human activities, have a strong impact on ecosystem services. Expansion of cultivated land, which especially caused the 
loss of grassland and forest land, directly exerted negative impacts on the provisioning of ecosystem services in the study area. As a result, many studies devoted to explore optimized land use management to improve the regional ecosystem services. In China, regional land use planning is an important measure for regional land use management, while current land use planning lacks of awareness of the value of ecosystem services, focuses more on economic benefit and ignores the protection of the green space, water, and other important ecosystems. Therefore, in order to maintain the sustainable development of the regional ecological system, it is necessary to assess the ESVs before the implementation of land use planning, and establish a set of real socio-economic-ecological benefit evaluation system for the integration of planning.

\section{Conflict of interest}

The authors declare that there is no conflict of interest regarding the publication of this paper.

\section{Acknowledgements}

This research was supported by the major research plan of the National Natural Science Foundation of China (Grant No. 91425303) and China National Natural Science Funds for Distinguished Young Scholar (Grant No. 71225005).

\section{References}

Ausseil, A.G.E., Dymond, J.R., Kirschbaum, M.U.F., Andrew, R.M., Parfitt, R.L., 2013. Assessment of multiple ecosystem services in New Zealand at the catchment scale. Environ. Modell. Softw. 43, 37-48.

Ayanu, Y.Z., Conrad, C., Nauss, T., Wegmann, M., Koellner, T., 2012. Quantifying and mapping ecosystem services supplies and demands: a review of remote sensing applications. Environ. Sci. Technol. 46, 8529-8541.

Bockstael, N.E., Freeman, A.M., Kopp, R.J., Portney, P.R., Smith, V.K., 2000. On measuring economic values for nature. Environ. Sci. Technol. 34, 1384-1389.

Burkhard, B., Kroll, F., Nedkov, S., Muller, F., 2012. Mapping ecosystem service supply, demand and budgets. Ecol. Indic. 21, 17-29.

Burkhard, B., Kroll, F., Müller, F., Windhorst, W., 2009. Landscapes'capacities to provide ecosystem services-a concept for land-cover based assessments. Landsc. Online 15, 1-22.

Chee, Y.E., 2004. An ecological perspective on the valuation of ecosystem services. Biol. Conserv, 120, 549-565.

Costanza, R., dArge, R., deGroot, R., Farber, S., Grasso, M., Hannon, B., Limburg, K., Naeem, S., ONeill, R.V., Paruelo, J., Raskin, R.G., Sutton, P., vandenBelt, M., 1997. The value of the world's ecosystem services and natural capital. Nature 387, 253-260.

Daily, G.C.E., 1997. Nature's Service: Societal Dependence on Natural Ecosystems. Island Press, Washington.

De Groot, R.S., Wilson, M.A., Boumans, R.M.J., 2002. A typology for the classification, description and valuation of ecosystem functions, goods and services. Ecol. Econ. 41, 393-408.

Deng, X.Z. Jiang, Q.O., Su, H.B., Wu, F., 2010. Trace forest conversions in Northeast China with a 1-km area percentage data model. J. Appl. Rem. Sens. 4, 041893.

Deng, X.Z., Li, Z.H., Huang, J., Shi, Q.L., Li, Y.F., 2013. A revisit to the impacts of land use changes on the human wellbeing via altering the ecosystem provisioning services. Adv Meteorol. 2013.

Deng, X.Z., Bai, X.M., 2014. Sustainable urbanization in Western China. Environ.: Sci. Policy Sustain. Develop. 56, 12-24.

Deng, X.Z., Zhao, C.H., 2015. Identification of water scarcity and providing solution for adapting to climate changes in the Heihe River Basin of China. Adv. Meteorol. 2015.

Egoh, B., Reyers, B., Rouget, M., Richardson, D.M., Le Maitre, D.C., van Jaarsveld, A.S. 2008. Mapping ecosystem services for planning and management. Agr. Ecosyst. Environ. 127, 135-140.
Farber, S.C., Costanza, R., Wilson, M.A., 2002. Economic and ecological concepts for valuing ecosystem services. Ecol. Econ. 41, 375-392.

Geneletti, D., 2013. Assessing the impact of alternative land-use zoning policies on future ecosystem services. Environ. Impact Asses. 40, 25-35.

Haines-Young, R., Potschin, M., Kienast, F., 2012. Indicators of ecosystem service potential at European scales: mapping marginal changes and trade-offs. Ecol. Indic. 21, 39-53.

Howarth, R.B., Farber, S., 2002. Accounting for the value of ecosystem services. Ecol. Econ. 41, 421-429.

Jackson, B., Pagella, T., Sinclair, F., Orellana, B., Henshaw, A., Reynolds, B., Mcintyre, N., Wheater, H., Eycott, A., 2013. Polyscape: a GIS mapping framework providing efficient and spatially explicit landscape-scale valuation of multiple ecosystem services. Landsc. Urban Plan 112, 74-88.

Leh, M.D.K., Matlock, M.D., Cummings, E.C., Nalley, L.L., 2013. Quantifying and mapping multiple ecosystem services change in West Africa. Agr. Ecosyst. Environ. 165, 6-18.

Liu, J.Y., Zhang, Z.X., Xu, X.L., Kuang, W.H., Zhou, W.C., Zhang, S.W., Li, R.D., Yan, C.Z., Yu, D.S., Wu, S.X., Nan, J., 2010. Spatial patterns and driving forces of land use change in China during the early 21st century. J. Geogr. Sci. 20, 483-494.

Li, Z.H., Deng, X.Z., Huang, J.K., Zhang, R.R., Huang, J., 2013. Critical studies on integrating land use induced effects on changes of climate regulation services into impact assessment of human well-being. Adv. Meteorol. 2013.

Li, Z.H., Deng, X.Z., Wu, F., Hasan, S.S., 2015. Scenario analysis for water resources in response to land use change in the middle and upper reaches of the Heihe River Basin. Sustainability 7, 3086-3018.

Müller, F., Burkhard, B., 2007. An ecosystem based framework to link landscape structures, functions and services. Multifunctional Land Use-Meeting Future Demands for Landscape Goods and Services. Springer, pp. 37-64.

Metzger, M.J., Rounsevell, M.D.A., Acosta-Michlik, L., Leemans, R., Schrotere, D., 2006. The vulnerability of ecosystem services to land use change. Agr. Ecosyst. Environ. 114, 69-85.

Naidoo, R., Balmford, A., Costanza, R., Fisher, B., Green, R.E., Lehner, B., Malcolm, T.R., Ricketts, T.H., 2008. Global mapping of ecosystem services and conservation priorities. Proc. Natl. Acad. Sci. U S A 105, 9495-9500.

Pereira, E., Queiroz, C., Pereira, H.M., Vicente, L., 2005. Ecosystem services and human well-being: a participatory study in a mountain community in Portugal. Ecol. Soc. 10.

Polasky, S., Nelson, E., Pennington, D., Johnson, K.A., 2011. The impact of land-use change on ecosystem services, biodiversity and returns to landowners: a case study in the State of Minnesota. Environ. Resour. Econ. 48, 219-242.

Radford, K.G., James, P., 2013. Changes in the value of ecosystem services along a rural-urban gradient: a case study of Greater Manchester, UK. Landsc. Urban Plan 109, 117-127.

Schroter, D., Cramer, W., Leemans, R., Prentice, I.C., Araujo, M.B., Arnell, N.W. Bondeau, A., Bugmann, H., Carter, T.R., Gracia, C.A., de la Vega-Leinert, A.C., Erhard, M., Ewert, F., Glendining, M., House, J.I., Kankaanpaa, S., Klein, R.J., Lavorel, S., Lindner, M., Metzger, M.J., Meyer, J., Mitchell, T.D., Reginster, I., Rounsevell, M., Sabate, S., Sitch, S., Smith, B., Smith, J., Smith, P., Sykes, M.T. Thonicke, K., Thuiller, W., Tuck, G., Zaehle, S., Zierl, B., 2005. Ecosystem service supply and vulnerability to global change in Europe. Science 310,1333-1337.

Tansley, A.G., 1935. The use and abuse of vegetational concepts and terms. Ecology $16,284-307$.

Troy, A., Wilson, M.A., 2006. Mapping ecosystem services: practical challenges and opportunities in linking GIS and value transfer. Ecol. Econ. 60, 435-449.

Wang, X.H., Zhang, Z.Q., 2004. Effect of land-use change on ecosystem services value in Heihe river basin. Ecol. Environ. 13, 608-611, in Chinese.

Wu, F., Zhan, J.Y., Yan, H.M., Shi, C.C., Huang, J., 2013. Land cover mapping based on multisource spatial data mining approach for climate simulation: a case study in the farming-pastoral ecotone of North China. Adv. Meteorol. 2013.

Wu, F., Zhan, J.Y., Su, H.B., Yan, H.M., Ma, E.J., 2015. Scenario-based impact assessment of land use/cover and climate changes on watershed hydrology in Heihe River Basin of Northwest China. Adv. Meteorol. 2015.

Xiao, S.C., Xiao, H.L., Peng, X.M., Song, X., 2015. Hydroclimate-driven changes in the landscape structure of the terminal lakes and wetlands of the China's Heihe River Basin. Environ. Monit. Assess. 187.

Xiao, S.C., Xiao, H.L., Peng, X.M., Tian, Q.Y., 2014. Daily and seasonal stem radial activity of Populus euphratica and its association with hydroclimatic factors in the lower reaches of China's Heihe River basin. Environ. Earth Sci. 72, 609-621.

Xie, G.D., Lu, C.X., Leng, Y.F., Zheng, D., Li, S.C., 2003. Ecological assets evaluation of the Tibetan Plateau. J. Nat. Resour. 18, 189-196, in Chinese.

Xie, G.D., Zhen, L., Lu, C.X., Xiao, Y., Chen, C., 2008. Expert knowledge based valuation method of ecosystem services in China. J. Nat. Resour. 23, 911-919, in Chinese. 